\title{
PENGARUH ETOS KERJA, KEPUASAN KERJA, SIKAP KERJA DAN MOTIVASI KERJA TERHADAP KINERJA PEGAWAI PADA KANTOR PELAYANAN PAJAK PRATAMA MEDAN POLONIA
}

\author{
Putra Arif Simanjuntak \\ Universitas Islam Sumatera Utara \\ putrai.arif@gmail.com
}

\begin{abstract}
The problems in this research are: How the influence of work ethic on employee performance at the Medan Polonia Tax Service Office, How the influence of job satisfaction on employee performance, How does the influence of work attitudes on employee performance, How does work motivation influence employee performance, How does work ethic influence, job satisfaction, work attitude and work motivation on employee performance at the Medan Polonia Primary Tax Service Office. The hypothesis proposed is: Work ethic has a positive and significant effect on employee performance at the Medan Polonia Tax Service Office, Job satisfaction has a positive and not significant effect on employee performance, work attitude has a positive and not significant effect on employee performance, work motivation has a positive and significant effect on employee performance, work ethic, job satisfaction, work attitude and work motivation have a positive and significant effect on employee performance at the Medan Polonia Tax Office. The study was conducted at the Medan Polonia Tax Office. Jalan Sukamulia No. 17-A, Medan-20151 with 92 research samples. Based on the analysis results obtained value of work ethic $t=2,900$, while $t$ table with dk 92 (Appendix) of 1.66, then $t$ count> t-table thus partially there is a significant influence between work ethic on employee performance. Value of t Job satisfaction $=1.838$, while $t$-table with dk 92 (Appendix) of 1.66, then $t$ count $>t$ table thus partially there is a significant influence between Job satisfaction on employee performance, Value of $t$ Attitude of work $=1,785$, while $t$-table with $d k 92$ (Appendix) of 1.66, then t count $>t$ table thus partially there is a significant influence between work attitude on employee performance, $t$ value of work motivation $=2.164$, while $t$-table with dk 92 (Attachment) equal to 1.66 then $t$ arithmetic $>t$ table thus partially there is a significant influence between work motives on employee performance, $F$-calculated value of 110.718 while the value of $F$-table (Appendix) with the numerator $d k 4$ and the denominator 87 is equal to 2.48 where F-count> F table (110.718> 2.48) it can be stated that together (multiple) there is a positive and significant influence on work ethics, job satisfaction, work attitude and motivation on employee performance wai
\end{abstract}

Keyword: Work ethic, job satisfaction, work attitude, work motivation and employee performance

ABSTRAK : Masalah dalam penelitian ini adalah:Bagaimana pengaruh etos kerja terhadap kinerja pegawai pada Kantor Pelayanan Pajak Pratama Medan Polonia, Bagaimana pengaruh kepuasan kerja terhadap kinerja pegawai, Bagaimana pengaruh sikap kerja terhadap kinerja pegawai, Bagaimana pengaruh motivasi kerja terhadap kinerja pegawai, Bagaimana pengaruh etos kerja, kepuasan kerja, sikap kerja dan motivasi kerja terhadap kinerja pegawai pada Kantor Pelayanan Pajak Pratama Medan Polonia. Hipotesis yang diajukan adalah :Etos kerja berpengaruh positif dan signifikan terhadap kinerja pegawai pada Kantor Pelayanan Pajak Pratama Medan Polonia, Kepuasan kerja berpengaruh positif dan tidak signifikan terhadap kinerja pegawai,Sikap kerja berpengaruh positif dan tidak signifikan terhadap kinerja pegawai, Motivasi kerja berpengaruh positif dan signifikan terhadap kinerja pegawai, Etos kerja, kepuasan kerja, sikap kerja dan motivasi kerja berpengaruh positif dan signifikan terhadap kinerja pegawai pada Kantor Pelayanan Pajak Pratama Medan Polonia.Penelitian dilakukan di Kantor Pelayanan Pajak Pratama Medan Polonia.Jalan Sukamulia No. 17-A, Medan-20151 dengan sampel penelitian sebanyak 92 orang. Berdasarkan hasil analisis diperoleh Nilai t Etos kerja $=2,900$, sedangkan t-tabel dengan dk 92 (Lampiran) sebesar 1,66 maka t hitung > t-tabel dengan demikian secara parsial ada pengaruh yang 
signifikan antara Etos kerja terhadap kinerja pegawai. Nilai t Kepuasan kerja $=1,838$, sedangkan ttabel dengan dk 92 (Lampiran) sebesar 1,66 maka t hitung $>t$ tabel dengan demikian secara parsial ada pengaruh yang signifikan antara Kepuasan kerja terhadap kinerja pegawai, Nilai t Sikap kerja $=1,785$, sedangkan t-tabel dengan dk 92(Lampiran) sebesar 1,66 maka $t$ hitung $>t$ tabel dengan demikian secara parsial ada pengaruh yang signifikan antara Sikap kerja terhadap kinerja pegawai, Nilai $\mathrm{t}$ motivasikerja $=2,164$, sedangkan $\mathrm{t}$-tabel dengan $\mathrm{dk}$ 92(Lampiran) sebesar 1,66 maka $\mathrm{t}$ hitung $>\mathrm{t}$ tabel dengan demikian secara parsial ada pengaruh yang signifikan antara motif kerja terhadap kinerja pegawai, Nilai F-hitung sebesar 110,718 sedangkan nilai F-tabel (Lampiran) dengan dk pembilang 4 dan dk penyebut 87 adalah sebesar 2,48 dimana F-hitung $>\mathrm{F}$ tabel $(110,718>2,48)$ maka dapat disebutkan bahwa secara bersama-sama (multiple) terdapat pengaruh positif dan signifikan Etos kerja, Kepuasan kerja, Sikap kerja dan motivasi terhadap kinerja pegawai

\section{Keyworld : Etos kerja, Kepuasan kerja, Sikap Kerja, Motivasi Kerja dan Kinerja Pegawai}

\section{Pendahuluan}

Pegawai merupakan aset penting dalam suatu instansi, tanpamereka betapa sulitnya instansi mencapai tujuan, merekalah yang menentukan maju mundurnya suatu instansi, dengan memiliki tenaga-tenaga kerja yang terampil dengan motivasi tinggi instansi telah mempunyai aset yang sangat mahal, sebab pada dasarnya manusia merupakan subyek dan obyek pembangunan yang merupakan faktor yang sangat penting, terutama peningkatan kualitas sumber daya manusia menjadi prioritas yang utama. Kinerja merupakan hal penting yang harus dicapai oleh setiap instansi termasuk padaKantor Pelayanan Pajak Pratama Medan Polonia, karena kinerja merupakan cerminan bagi kemampuan instansi dalam mengelola dan mengalokasikanpegawainya,olehkarena itu kinerja para pegawai mempunyai pengaruh yang sangat penting bagi berlangsungnya kegiatan instansi dan berpengaruh bagi proses pencapaian tujuan instansi.

Kantor Pelayanan Pajak Pratama Medan Polonia merupakan suatu instansi yang melakukan pemungutan pajak untuk wilayah Medan Polonia, dimana keberhasilan pelaksanaan tugasdantanggung jawab Kantor Pelayanan Pajak Pratama Medan Polonia tergantung pada kinerja para pegawai yang ada. Pentingnya kinerja pegawai yang ada pada Kantor Pelayanan Pajak Pratama Medan Polonia sangat berpengaruh terhadap pelaksanaan tujuan instansi itu, yaitu untuk meningkatkan pelayanan terhadap para masyarakat atau wajib pajak dengan dilandasi kesetiaan dan ketaatan kepada Pancasila dan Undang-Undang Dasar 1945. Untuk dapat melaksanakan tugas dengan baik, maka pembinaan pegawai diarahkan untuk meningkatkan kualitas sumber daya manusia agar memiliki sikap dan perilaku yang berintikan pengabdian, kejujuran, profesional, tanggung jawab, disiplin, etos kerja, komitmen organisasi serta wibawa sehingga dapat memberikan pelayanan sesuai tuntutan perkembangan masyarakat.

Menurut Robbins (2006:170), untuk mendapatkan kinerja yang baik dan hasil kerja yang meningkat di suatu organisasi kerja, pegawai harus memenuhi persyaratan atau memiliki diantaranya keahlian dan kemampuan dasar, yaitu sekelompok kemampuan, yang meliputi kemampuan komunikasi, kemampuan teknik, kemampuan konseptual, serta kualitas pribadi yang meliputimental, fisik, emosi, watak sosial, sikap, komitmen, integritas, kesadaran, serta perilaku yang baik, dan kemampuan administrasi meliputi kemampuan menganalisis persoalan, memberi pertimbangan, pendapat, keputusan, mengatur sumber daya,dan berbagai macam kegiatan, lapang dada, sabar, berpartisipasi aktif dalam berbagai aktivitas.

Etos kerja adalah seperangkat perilaku kerja positif yang berakar pada kerjasamayang kental, keyakinan yang fundamental, disertai komitmen yang total pada paradigm kerja yang integral. Etos kerja yang tinggi seyogyanya harus dimiliki oleh setiap pegewai karena setiap organisasi sangat membutuhkan kerja keras dan komitmen yang tinggi setiap pegawai, kalau tidak organisasi akan sulit berkembang, dan memenangkan persaingn dalam merebut pangsa pasarnya. Setiap organisasi yang selalu ingin maju, akan melibatkan anggota untuk kinerjanya, diantaranya setiap organisasi harusmemilikietos kerja.Individu ataukelompok masyrakat dapat dinyatakan 
memilikietoskerjayang tinggi.Etoskerja yang dimilikiolehseseorang ataukelompok masyarakat,akanmenjadisumber motivasi bagi perbuatannya. Etos kerja pegawai pada Kantor Pelayanan Pajak Pratama Medan Polonia belum seperti yang diharapkan, ini terlihat dari masih adanya pegawai yang kurang disiplin menjalankan peraturan dan prosedur kerja yang ditetapkan instansi, masih ada pegawai kurang jujur dalam melaporkan hasil pekerjaannya.

Disisi lain, Kepuasan kerja selalu dikaitkan dengan kinerja pegawai. Hal ini berarti untuk dapat meningkatkan kinerja pegawai, organisasi harus mampu memenuhi dan meningkatkan kepuasan kerja pegawainya. Terry (2011:111) menyatakan bahwa kepuasan kerja adalah seperangkat perilaku kerja positif yang berakar pada kesadaran yang kental, keyakinan yang fundamental, disertai komitmen yang total pada paradigma kerja yang integral. Istilah paradigma di sini berarti konsep utama tentang kerja itu sendiri yang mencakup idealisme yang mendasari, prinsip-prinsip yang mengatur, nilai-nilai yang menggerakkan, sikap-sikap yang dilahirkan, standar-standar yang hendak dicapai. termasuk karakter utama, pikiran dasar, kode etik, kode moral, dan kode perilaku bagi para pemeluknya. Penelitian dari Noviansyah dan Zunaidah (2011) menyatakan kepuasan kerja berpengaruh positif dan signifkan terhadap kinerja

Menurut Ivancevich (2007:88), sikap kerja merupakan keadaan mental yang dipelajari dan diorganisasikan melalui pengalaman, menghasilkan pengaruh spesifik pada respons seseorang terhadap orang lain, objek, dan situasi yang berhubungan. Orang mencari kesesuaian antara keyakinan dan perasaan mereka terhadap objek dan menyatakan bahwa modifikasi sikap dapat dilakukan dengan mengubah sisi perasaan atau keyakinan tersebut, teori tersebut berpendapat bahwa kognisi, afeksi dan perilaku menentukan sikap dan bahwa sikap pun pada akhirnya menentukan kognisis, afeksi dan perilaku.

Dalam suatu organisasi motivasi kerja pegawai sangat diperlukan untuk mencapai suatu tujuan yang telah ditetapkan bersama. Dengan pemberian motivasi diharapkan setiap individu pegawai mau bekerja sama, bekerja efektif dan antusias untuk mencapaikinerja yang tinggi, karena menurut Hasibuan (2011) kemampuan dan kecakapan yang dimiliki pegawai tidak ada artinya bagi organisasi jika mereka tidak termotivasi untuk bekerja. Motivasi yang ada pada diri seseorang merupakan kekuatan pendorong yang akan mewujudkan suatu perilaku guna mencapai tujuan kepuasan (dirinya). Karena motivasi sebagai kesediaan untuk mengeluarkan tingkat upaya yang tinggi untuk tujuan organisasi yang dikondisikan oleh kemampuan upaya dalam memenuhi beberapa kebutuhan individu (Robbins, 2017:88). Apabila motivasi untuk melaksanakan perkerjaan tinggi, diharapkan hasil kinerja akan maksimal. Sebaliknya apabila motivasi kerja rendah, maka kinerja yang dihasilkan tidak akan optimal. Dari hasil survei penelitian di Kantor Pelayanan Pajak Pratama Medan Polonia ditemukan bahwa motivasi pegawai bekerja masih belum optimal, hal ini dapat disebabkan karena target pajak yang belum tercapai dan kreativitas untuk memberikan pelayanan yang optimal kepada wajib pajak masih perlu peningkatan.

Agar permasalahan yang dikaji terarah maka permasalahan dibatasi sebagai berikut. Penelitian ini hanya membahas faktoretos kerja, kepuasan kerja, sikap kerja, motivasi kerja dan kinerja. Dan tujuan penelitian ini adalah :

a. Untuk mengetahui dan menganalisis pengaruh etos kerja terhadap kinerja pegawai pada Kantor Pelayanan Pajak Pratama Medan Polonia.

b. Untuk mengetahui dan menganalisis pengaruh kepuasan kerja terhadap kinerja pegawai pada Kantor Pelayanan Pajak Pratama Medan Polonia.

c. Untuk mengetahui dan menganalisis pengaruh sikap kerja terhadap kinerja pegawai pada Kantor Pelayanan Pajak Pratama Medan Polonia.

d. Untuk mengetahui dan menganalisis pengaruh motivasi kerja terhadap kinerja pegawai pada Kantor Pelayanan Pajak Pratama Medan Polonia.

e. Untuk mengetahui dan menganalisis pengaruh etos kerja, kepuasan kerja, sikap kerja dan motivasi kerja terhadap kinerja pegawai pada Kantor Pelayanan Pajak Pratama Medan Polonia.

\section{Metode Penelitian}

\subsection{LokasiPenelitian}

Lokasi penelitian dilakukan di Kantor Pelayanan Pajak Pratama Medan Polonia.Jalan Sukamulia No. 17-A, Medan-20151. 


\subsection{Populasi}

Populasi juga bukan sekedar jumlah yang ada pada objek/subjek yang dipelajari, tetapi meliputi seluruh karakteristik, sifat yang dimiliki objek/subjek itu. Dari pengertian tersebut, maka dapat disimpulkan bahwa populasi merupakan subjek penelitian dimana individu yang akan dikenai perilaku atau dapat dikatakan sebagai keseluruhan objek penelitian yang akan diteliti. Populasi dalam penelitian ini adalah pegawai Kantor Pelayanan Pajak Pratama MedanPolonia yang berjumlah 119 orang dimana peneliti tidak dijadikan populasi, dengan rincian sebagai berikut.

Tabel 1

Kerangka populasi berdasarkan jabatan

\begin{tabular}{|c|l|c|}
\hline No & \multicolumn{1}{|c|}{ Keterangan/Jabatan } & $\begin{array}{c}\text { Jumlah } \\
\text { (Orang) }\end{array}$ \\
\hline 1 & Kepala Kantor & 1 \\
\hline 2 & Kepala Seksi & 10 \\
\hline 3 & Account Representative & 49 \\
\hline 4 & Fungsional & 19 \\
\hline 5 & Pelaksana & 40 \\
\hline \multicolumn{2}{|c|}{ Jumlah } & 119 \\
\hline
\end{tabular}

Sumber : Kantor Pelayanan Pajak Pratama Medan Polonia, 2019

\subsection{Sampel}

Untuk menentukan jumlah sampel, digunakan pendapat Slovin dalam Sekaran dan Bougie (2010:112) dengan menggunakan formula sebagai berikut :

Keterangan :

$$
n=\frac{N}{1+N \mathrm{e}^{2}}
$$

n : Jumlah Sampel

$\mathrm{N}$ : Jumlah Populasi

$$
e \text { : Kesalahan }
$$

ditolerirdalampenarikansampelyaitu 0,05 .

yang

Berdasarkan formula diatas, selanjutnya dapat dihitung jumlah sampel dalam penelitian ini sebagai berikut :

$$
\begin{aligned}
& \mathrm{n}=\frac{119}{1+119(0,05)^{2}} \\
& \mathrm{n}=\frac{119}{1.297} \\
& \mathrm{n}=91.75=92 \text { orang }
\end{aligned}
$$

Setelah perhitungan di atas, penetapan jumlah sampel dalam penelitian ini menggunakan metode stratified random sampling yaitu penarikan sampel berdasarkan pada strata populasi pada setiap bagian, sehingga sampel dalam penelitian ini berjumlah 92 orang pegawai, dengan rincian sebagai berikut :

Tabel 2

Kerangka sampel berdasarkan jabatan

\begin{tabular}{|c|l|c|}
\hline No & \multicolumn{1}{|c|}{ Keterangan/Jabatan } & $\begin{array}{c}\text { Jumlah } \\
\text { (Orang) }\end{array}$ \\
\hline 1 & Kepala Seksi & 7 \\
\hline 2 & Account Representative & 40 \\
\hline 3 & Fungsional & 15 \\
\hline 4 & Pelaksana & 30 \\
\hline \multicolumn{2}{|c|}{ Jumlah } & 92 \\
\hline
\end{tabular}

Sumber : Kantor Pelayanan Pajak Pratama Medan Polonia, 2019

\subsection{Defenisi Operasional}

Terdapat dua variabel dalam penelitian ini, variabel-variabel tersebut adalah Variabel Terikat, yaitu kinerja (Y), Variabel Bebas adalah Etos Kerja $\left(\mathrm{X}_{1}\right)$, Kepuasan Kerja $\left(\mathrm{X}_{2}\right)$, Sikap Kerja $\left(\mathrm{X}_{3}\right)$, Motivasi $\left(\mathrm{X}_{4}\right)$.

\subsection{Teknik Pengumpulan Data}

Teknik pengumpulan data dilakukan dengan pengumpulan data primer yaitu data yang dikumpulkan dari sumber-sumber asli untuk tujuan tertentu, atau data yang diperoleh dengan survei lapangan yang menggunakan metode pengumpulan data ordinal, yaitu : wawancara, Kuesioner.

\subsection{Teknik Analisa Data}

Teknik analisis data menggunakan validitas dan realibilitas, uji asumsi klasik dengan menggunakan uji Multikolinearitas, Multikolinearitas, Uji Heteroskedastisitas. Pengujian Hipotesis menggunakan uji regresi berganda.

\section{Analisa dan Pembahasan}

\subsection{Analisis Regresi}

Setelah dilakukan uji asumsi klasik maka dapat dilakukn untuk penggunaan analisis regresi. Analisis regresi digunakan untuk menganalisis data hasil penelitian dengan maksud untuk memperoleh gambaran hubungan fungsional antara variabel bebas dengan variabel terikat Hubungan fungsional antara variabel bebas dengan variabel terikat digunakan analisis regresi linier berganda

Berdasarkan analisis regresi linier ganda (Multiple) sebagaimana pada tabel 3 diperoleh koefisien regresi sebagai berikut. 
Tabel 3

Koefisien Regresi

\begin{tabular}{|ll|l|l|l|l|l|}
\hline \multicolumn{2}{|l|}{ Model } & \multicolumn{2}{|l|}{ Unstandardized Coefficients } & $\begin{array}{l}\text { Standardized } \\
\text { Coefficients }\end{array}$ & T & Sig. \\
\cline { 3 - 5 } & & $\mathrm{B}$ & Std. Error & Beta & & \\
\hline \multirow{4}{*}{1} & (Constant) & 5.258 & 1.485 & & 3.541 & .001 \\
& Etos kerja & .323 & .111 & .315 & 2.900 & .005 \\
& Kepuasan kerja & .214 & .117 & .189 & 1.838 & .069 \\
& Sikap kerja & .244 & .137 & .214 & 1.785 & .078 \\
& Motivasi & .259 & .120 & .243 & 2.164 & .033 \\
\hline
\end{tabular}

Sumber : Hasil SPSS, 2019

Berdasarkan table 5.18diperoleh koefisien regresi variabel Etos kerja 0,323;Kepuasan kerja $=0,214$, Sikap kerja 0,244, motivasi 0,259dengan konstanta 5,258, maka dapat dituliskan persamaan regresi sebagai berikut.

$$
\begin{gathered}
Y=5,258+0,323 X_{1}+0,214 X_{2}+0,244 X_{3}+ \\
0,259 X_{3}
\end{gathered}
$$

Persamaan di atas menunjukkan konstanta bernilai positip dan nilai koefisien regresi juga positip. Hal ini memberi gambaran bahwa perubahan rata-rata variabel kinerja pegawai (Y) tergantung dari perubahan variabel Etos kerja $\left(\mathrm{X}_{1}\right)$, Kepuasan kerja $\left(\mathrm{X}_{2}\right)$ sikap kerja $\left(\mathrm{X}_{3}\right)$ dan motivasi. Artinya apabila Etos kerja, Kepuasan kerja, Sikap kerja dan motivasi ditingkatkan (semakin baik) akan diikuti perubahan/peningkatan kinerja pegawai. Perubahan ini merupakan peningkatan apabila bertanda positip dan penurunan atau pengurangan jika bertanda negatif. Hal ini menunjukkan bahwa ada pengaruh etos kerja, Kepuasan kerja, Sikap kerjadan motivasi terhadap kinerja pegawai.

\subsection{Uji Hipotesis}

\subsubsection{Uji t- (Parsial)}

Untuk mengetahui pengaruh variabel bebas terhadap variabel terikat secara parsial digunakan uji $\mathrm{t}$ dengan uji satu pihak, dimana dengan ketentuan :

$\mathrm{t}$ - hitung $\leq \mathrm{t}$ - tabel ...............tidak ada pengaruh variabel bebas terhadap variabel terikat secara parsial

t- hitung > t- tabel ................Ada pengaruh variabl bebas terhadap variabel terikat secara parsial

derajat kebebasan $(\mathrm{dk})=\mathrm{n}-2$ dan Tingkat kepercayaan $\alpha=0,05$,

Tabel 4

Uji - t (Parsial)

\begin{tabular}{|c|c|c|c|c|c|c|}
\hline \multirow{2}{*}{\multicolumn{2}{|c|}{ Model }} & \multicolumn{2}{|c|}{ Unstandardized Coefficients } & \multirow{2}{*}{$\begin{array}{c}\begin{array}{c}\text { Standardized } \\
\text { Coefficients }\end{array} \\
\text { Beta }\end{array}$} & \multirow[b]{2}{*}{$\mathrm{t}$} & \multirow[b]{2}{*}{ Sig. } \\
\hline & & $\mathrm{B}$ & Std. Error & & & \\
\hline \multirow[t]{5}{*}{1} & (Constant) & 5.258 & 1.485 & & 3.541 & .001 \\
\hline & Etos kerja & .323 & .111 & .315 & 2.900 & .005 \\
\hline & Kepuasan kerja & .214 & .117 & .189 & 1.838 & .069 \\
\hline & Sikap kerja & .244 & .137 & .214 & 1.785 & .078 \\
\hline & Motivasi & 259 & .120 & .243 & 2.164 & .033 \\
\hline
\end{tabular}

Coefficients $^{\mathrm{a}}$

a. Dependent Variable: Kinerja pegawai

Berdasarkan hasil analisis pada tabel 5.18 diatas; diperoleh nilai tEtos kerja $=2,900$, sedangkan t-tabel dengan $\mathrm{dk} 92$ (Lampiran) sebesar 1,66 maka thitung > t-tabel dengan demikian secara parsial ada pengaruh yang signifikan antara Etos kerja terhadap kinerja pegawai.

Selanjutnya nilai t Kepuasan kerja $=1,838$, sedangkan t-tabel dengan $\mathrm{dk} 92$ (Lampiran) sebesar 1,66 maka t hitung > t tabel dengan demikian secara parsial ada pengaruh yang 
signifikan antara Kepuasan kerja terhadap kinerja pegawai..

Nilai t Sikap kerja $=1,785$, sedangkan ttabel dengan dk 92(Lampiran) sebesar 1,66 maka $\mathrm{t}$ hitung $>\mathrm{t}$ tabel dengan demikian secara parsial ada pengaruh yang signifikan antara Sikap kerja terhadap kinerja pegawai

Nilai t motivasikerja $=2,164$, sedangkan $\mathrm{t}$-tabel dengan dk 92(Lampiran) sebesar 1,66 maka $t$ hitung $>\mathrm{t}$ tabel dengan demikian secara parsial ada pengaruh yang signifikan antara motif kerja terhadap kinerja pegawai

\subsubsection{Uji F (Mulktipel)}

Untuk mengetahui pengaruh variabel bebas secara bersama-sama terhadap variabel terikat digunakan uji-F, (Sudjana, 2013:355) dengan rumus:

$$
: F_{\text {hit }}=\frac{J K_{r e g} / k}{J K_{r e s} /(n-k-1)}
$$

Dimana :

$\mathrm{JK}_{\text {reg }}=$ Jumlah kuadrat regresi

$\mathrm{JK}_{\mathrm{reg}}=$ Jumlah kuadrat residu

$\mathrm{n} \quad=$ Jumlah Sampel

$\mathrm{K}=$ Jumlah varians

Jika : $\mathrm{F}$ hitung $>\mathrm{F}$ tabel : Hipotesis Alternatip (Ha) diterima

$\mathrm{F}$ hitung $<\mathrm{F}$ tabel : Hipotesis $(\mathrm{Ho})$ ditolak

Penelitian ini menggunakan tingkat kepercayaan $95 \%(\alpha=0.05)$

Tabel 5

Uji - F (Simultan)

ANOVA $^{\mathrm{a}}$

\begin{tabular}{|ll|r|r|r|r|c|}
\hline \multicolumn{2}{|l|}{ Model } & \multicolumn{1}{|c|}{$\begin{array}{c}\text { Sum of } \\
\text { Squares }\end{array}$} & df & Mean Square & F & Sig. \\
\hline 1 & Regression & 1212.942 & 4 & 303.235 & 110.718 & $.000^{\mathrm{b}}$ \\
& Residual & 238.276 & 87 & 2.739 & & \\
& Total & 1451.217 & 91 & & & \\
\hline
\end{tabular}

a. Dependent Variable: Kinerja pegawai

b. Predictors: (Constant), Motivasi, Kepuasan kerja, Etos kerja, Sikap kerja

Berdasarkan analisis varians (Anova) pada lampiran 10 diketahui nilai F-hitung sebesar 110,718sedangkan nilai F-tabel (Lampiran) dengan dk pembilang 4 dan $\mathrm{dk}$ penyebut 87 adalah sebesar 2,48 dimana F-hitung $>\mathrm{F}$ tabel $(110,718>2,48)$ maka dapat disebutkan bahwa secara bersama-sama (multiple) terdapat pengaruh positif dan signifikan Etos kerja, Kepuasan kerja, Sikap kerja dan motivasi terhadap kinerjapegawai. Dengan demikian hipotesis yang diajukan diterima kebenarannya.

\subsection{Uji Determinasi}

Berdasarkan hasil analisis data Etos kerja di Kantor Pelayanan Pajak Pratama Medan Poloniacenderung kurang baik. Kepuasan kerja kurang puas, Sikap kerja jugatidak positip, motivasi rendah dan kinerja pegawai juga kurang tinggi.Berdasarkan hasil analisis data sesuai hasil ANOVA kinerja pegawai dapat meningkat apabilaEtos kerja semakin baik, Kepuasan kerja semakin puas/baik dan Sikap kerja semakin positip dan motivasi kerja semakin tinggi. Oleh sebab itu juga pengujian hipotesis diperoleh terdapat pengaruh signifikan Etos kerja, Kepuasan kerja, Sikap kerja, motivasiterhadap kinerja pegawai. Apabila Etos kerja, Kepuasan kerja, Sikap kerja, motivasi ditingkatkan $1 \%$ maka kinerja pegawai akan naik $1 \%$. Besarnya pengaruh motivasi kerjai, Kepuasan kerja, Sikap kerja dan motivasi terhadap Kinerja pegawai dapat diketahui melalui uji determinasi (D) dimana $D=R^{2} x$ $100 \%$. Hasil analisis pada model summary sebagaimana pada lampiran 10 sebagai berikut.

Tabel 6

Model Summary

\begin{tabular}{|l|l|l|l|l|l|}
\hline Model & $\mathrm{R}$ & R Square & $\begin{array}{l}\text { Adjusted R } \\
\text { Square }\end{array}$ & $\begin{array}{l}\text { Std. Error of } \\
\text { the Estimate }\end{array}$ & $\begin{array}{l}\text { Durbin- } \\
\text { Watson }\end{array}$ \\
\hline 1 & $.914^{\mathrm{a}}$ & .836 & .828 & 1.65493 & 1.473 \\
\hline
\end{tabular}

a. Predictors: (Constant), Motivasi, Kepuasan kerja, Etos kerja, Sikap kerja

b. Dependent Variable: Kinerja pegawai 
Berdasarkan tabel 5.18 diketahui $\mathrm{R}^{2}=0,871$ maka $\mathrm{D}=0,836 \mathrm{x} 100 \%$ sehingga $\mathrm{D}=83,6 \%$. Akan tetapi dalam regresi multiple lebih baik digunakan nilai adjusted $\mathrm{R}$ Square $=$ 0,828Dengan demikian pengaruh Etos kerja, Kepuasan kerja, Sikap kerja dan motivasi terhadap kinerja pegawaisebesar $82,6 \%$. sedangkan $17,4 \%$ lagi yang mempengaruhi kinerja pegawai di Kantor Pelayanan Pajak Pratama Medan Poloniaditentukan faktor lain yang tidak diteliti dalam penelitian ini.

\section{Kesimpulan}

Sesuai hasil analisis penelitian maka dapat diambil kesimpulan sesuai tujuan penelitian yang dikemukakan.

a. Nilai t Etos kerja $=2,900$, sedangkan t-tabel dengan dk 92 (Lampiran) sebesar 1,66 maka t hitung > t-tabel dengan demikian secara parsial ada pengaruh yang signifikan antara Etos kerja terhadap kinerja pegawai.

b. nilai t Kepuasan kerja $=1,838$, sedangkan ttabel dengan dk 92 (Lampiran) sebesar 1,66 maka $\mathrm{t}$ hitung $>\mathrm{t}$ tabel dengan demikian secara parsial ada pengaruh yang signifikan antara Kepuasan kerja terhadap kinerja pegawai..

c. Nilai t Sikap kerja $=1,785$, sedangkan ttabel dengan dk 92(Lampiran) sebesar 1,66 maka $\mathrm{t}$ hitung $>\mathrm{t}$ tabel dengan demikian secara parsial ada pengaruh yang signifikan antara Sikap kerja terhadap kinerja pegawai

d. Nilai t motivasikerja $=2,164$, sedangkan $\mathrm{t}$ tabel dengan dk 92(Lampiran) sebesar 1,66 maka $\mathrm{t}$ hitung $>\mathrm{t}$ tabel dengan demikian secara parsial ada pengaruh yang signifikan antara motif kerja terhadap kinerja pegawai

e. Nilai F-hitung sebesar 110,718 sedangkan nilai F-tabel (Lampiran) dengan $\mathrm{dk}$ pembilang 4 dan dk penyebut 87 adalah sebesar 2,48 dimana F-hitung > F tabel $(110,718>2,48)$ maka dapat disebutkan bahwa secara bersama-sama (multiple) terdapat pengaruh positif dan signifikan Etos kerja, Kepuasan kerja, Sikap kerja dan motivasi terhadap kinerja pegawai

\section{DAFTAR PUSTAKA}

Abdullah, Z., Darwanis., dan Zein, B. (2013). Pengaruh Stres Kerja terhadap Kinerja Auditor Melalui Motivasi Kerja sebagai Variabel Intervening. Jurnal Akuntansi, Volume 2, No. 1, November 2012

Altangerel, O., Ruimei, W., Elahi, E., dan Dash, B. (2015). Investigating The Effect Of Job
Stress and Motivation On Performance of Employees. International Journal of Scientific \& technology research Vol 4 Issue 02.

Anwar, A.B., Maupa, H., Ali, M., dan Ismail, M. (2015). The Effects of Work Stress and Compensation on the Employees' Performance through Motivation and Job Satisfaction at the Private Life Insurance Companies in Jakarta, Indonesia. Scientific Research Journal (SCIRJ), Volume III, Issue IX

Arief, C.A., dan Farid, W. (2011). Pengaruh Kepemimpinan, Stres Kerja, Disiplin Kerja dan Kompensasi terhadap Kinerja Pegawai. Jurnal Ekonomi Manajemen Sumber DayaVol. 12, No. 1

Arikunto, Suharsismi. (2002). Prosedur Penelitian Suatu Pendekatan Praktek. Jakarta: Rineka Cipta.

Azmi, F.S., Shahid, S.A., dan Alwi, A. (2016). The Relationship between Job Stress and Front-liners' Job Performance in a Shared Service Center in Malaysia. International Journal of Social Science and Humanity, Vol. 6, No. 7.

Cross, T.Mdan Lynch. R.R. (2012). Peniliaian dan Evaluasi Kinerja: Konsep dan Praktik. Jakarta. Penerbit Ghalia Indonesia

David, Fred. R (2011), The Balanced Scorecard, Scientific Research Journal (SCIRJ),

Dessler, Gary. (2012). Manajemen Sumber Daya Manusia (Jilid I). Jakarta : Indeks.

Fauzi, A. (2013). Pengaruh Kepemimpinan, Kecerdasan Emosional dan Motivasi terhadap Kepuasan Kerja Guru di SMA. Jurnal Manajemen Pendidikan Vol 1, No 1

Hasibuan, Malayu S. P. (2011). Manajemen Sumber Daya Manusia. Edisi Revisi Jakarta: PT. Bumi Aksara.

Mahiri, E., dan Orwa, B.H. (2016). Occupational Stress and Employee Performance: A Case Study of Kenya National Highways Authority (KeNHA). International Journal of Education and Research Vol. 4 No. 1

Mangkunegara, Anwar, Prabu. (2009). Evaluasi Kinerja SDM, Cetakan 4, Bandung : Refika Aditama

Mangkuprawira, Sjafri. (2014). Manajemen Sumber Daya Manusia Strategik. Cetakan ketiga, Penerbit Ghalia Indonesia

Noviansyah dan Zunaidah (2011). Pengaruh Stres Kerja Dan Motivasi Kerja Terhadap 
Kinerja PegawaiPT. Perkebunan Minanga Ogan Baturaja. Jurnal Manajemen dan Bisnis Sriwijaya Vol.9 No.18.

Riduwan. (2014). Skala Pengukuran VariabelVariabel Bandung : Alfabeta

Robbins S.P \& Judge,T.A. 2017. Perilaku Organisasi. Buku 1 Edisi 12. Terjemahan Diana Angelica. Penerbit Salemba Empat. Jakarta.

Robbins, Stephen P. (2016). Perilaku Organisasi. Edisi kesepuluh. Jakarta: Indeks Kelompok Gramedia.

Rosneli dan Septiani (2008). Pengaruh Stres Kerja terhadap Kinerja Pegawai pada bagian Redaksi Surat kabar Harian Umum Lampung Post. Jurnal Bisnis dan Manajemen Vol 4 No 2

Rush, Michael dan Althoff, Phillip.(2013). Pengantar Sosiologi Politik. Jakarta: PT. Raja Grafindo Persada.

Samsudin, Sadili. (2009). Manajemen Sumber Daya Manusia. Bandung: CV. Pustaka Setia.

Sedarmayanti. (2004). Good Governance (Kepemerintahan Yang Baik), Bandung : Mandar Maju

Sekaran,U., dan Bougie (2010), Research Methods for Busines. A Skill Building Approach. Fifth Edition. A John Wiley and Sons, Ltd, Publication.

Siagian, Sondang. (2012). Manajemen Sumber Daya Manusia (cetakan 15). Jakarta: Bumi Aksara

Sink, Rdan Tuttle, J.K. (2008). Evaluasi Kinerja. Jakarta: Indeks Kelompok Gramedia.

Sugiyono. (2009). Metode Penelitian Kuantitatif dan Kualitatif dan $R$ \& $D$. Bandung : Alfabeta

Suliyanto. (2011). Ekonometrika Terapan : Teori \& Aplikasi dengan SPSS. CV Andi Offset

Thoha, Miftah. (2001). Birokrasi Indonesia Dalam Era Globalisasi, Pusdiklat Pegawai Depdiknas, Sawangan, Bogor.

Terry George dan Rue, Leslie W alih bahasa Sadeli (2012), Dasar-Dasar Manajemen, Cetakan Ketujuh Bumi Aksara Jakarta.

Triton PB (2013), Paradigma Baru Manajemen Sumber Daya Manusia, Tugu Yogyakarta. (2006), SPSS 12.00 Terapan Riset Statistik Parametrik, Andi Yogyakarta.
Yukl,

G. 2007.Kepemimpinan DalamOrganisasi.Edisi Indonesia (kelima). Cetakankedua. Penerbit PT Indeks, Jakarta.

Zauhar. S. 2001. Reformasi Birokrasi. Universitas Brawijaya Malang

Peraturan Pemerintah No. 100 Tahun 2000, Tentang Pengangkatan Pegawai Negeri Sipil Dalam Jabatan Struktural. 